\title{
IEAATOTUKA
}

\author{
UDC 811'111:378.4.091.31-059.1 \\ DOI https://doi.org/10.24919/2308-4863/35-7-29
}

Larysa ANDREIKO, orcid.org/0000-0002-6294-6737 Candidate of Philological Sciences, Associate Professor at the Foreign Languages Department of Education and Research Institute for Business Technologies "UAB"

of Sumy State University (Sumy,Ukraine) l.andreiko@uabs.sumdu.edu.ua

Alla KHODTSEVA, orcid.org/0000-0003-4226-0866 Candidate of Pedagogical Sciences, Associate Professor at the Foreign Languages Department of Education and Research Institute for Business Technologies "UAB"

of Sumy State University (Sumy, Ukraine) a.khodtseva@uabs.sumdu.edu.ua

\section{COOPERATIVE LEARNING IN THE EFL CLASSROOM WITH FIRST-YEAR UNIVERSITY STUDENTS}

The article explores the concept of cooperative learning (CL) and how it can be used effectively in teaching English to first-year students. By CL we mean a method of instruction where students work in small groups to maximize their own and each other learning. Developing collaborative skills is especially essential for first-year students who are often not very-well prepared for group-work and effective collaboration. They are often convinced that they can only learn from the teacher, not from each other. The analysis and synthesis of the literature helped identify the core features of CL and the challenges teachers and students often struggle with. Such fundamental principles of CL as positive interdependence and individual accountability were stressed. Positive interdependence means working as a team towards a shared goal, not in competition with each other. Individual accountability describes a situation when each group member contributes to the group success and is accountable both for their own learning and for contributing to the group. Cooperative learning activities which are instrumental in promoting positive interdependence and individual accountability were suggested. Each of the following activities was described: Jigsaw, Circle the Sage, Numbered Heads Together, Student Team Achievement Divisions. The importance of preparing students for collaborative activities and building the culture of collaboration was highlighted. Four main obstacles in relation to CL were distinguished: lack of collaborative skills, free-riding, competence status and friendship. The need to train students do deal with these obstacles was emphasized. Strategies for enhancing and facilitating productive cooperation were outlined such as assigning roles to group members, having permanent groups, keeping groups small, teaching how to collaborate. Positive aspects of setting CL goals, instructing students explicitly in the collaborative skills necessary for effective collaboration and having detailed criteria to assess how students work in groups were accentuated.

Key words: cooperative learning, collaborative learning, collaborative skills, EFL classroom, positive interdependence, individual accountability, group work.

Лариса АНДРЕЙКО, orcid.org/0000-0002-6294-6737 кандидат філологічних наук, дочент кафедри іноземних мов Навчально-наукового інституту бізнес-технологій «УАБС»

Сумського державного університету (Суми, Украӥна) l.andreiko@uabs.sumdu.edu.иа 


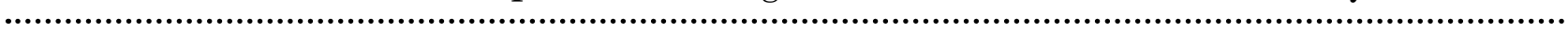 \\ Алла ХОДЦЕВА, \\ orcid.org/0000-0003-4226-0866 \\ кандидат педагогічних наук, \\ доиент кафедри іноземних мов \\ Навчально-наукового інституту бізнес-технологій «УАБС» \\ Сумського державного університету \\ (Суми, Україна) a.khodtseva@uabs.sumdu.edu.ua
}

\section{ГРУПОВІ ФОРМИ РОБОТИ НА ЗАНЯТТЯХ З АНГЛІЙСЬКОЇ МОВИ НА ПЕРШОМУ КУРСІ ВНЗ}

\begin{abstract}
У статті розглядається поняття «сумісне навчання» та те, як його ефективно використовувати у викладанні англійської мови студентам першого курсу. Під сумісним навчанням ми розуміємо метод навчання, коли студенти працюють у малих групах з метою максимізувати потенціал кожного в групі. Розвиток навичок співпраці особливо важливий для студентів першого курсу, які часто не дуже добре підготовлені до групової роботи та ефективної співпраці. Вони часто переконані, що можуть вчитисялише увикладача, ане одинуодного. Аналіз та синтез літератури допомогли визначити основні риси сумісного навчання та проблеми, з якими часто стикаються викладачі та студенти. Наголошено на таких фундаментальних принципах сумісного навчання, як позитивна взаємозалежність та індивідуальна відповідальність. Позитивна взаємозалежність означає роботу в команді задля спільної мети, а не конкуренції між собою. Індивідуальна відповідальність виникає, коли кожен учасник групи сприяє успіху групи і відповідає як за своє навчання, так $і$ за внесок у групу. Запропоновано види навчальної діяльності, які сприяють позитивній взаємозалежності та індивідуальній відповідальності на заняттях з англійської мови. Детально описаний кожен з видів діяльності. Підкреслено важливість підготовки студентів до сумісної діяльності та формування культури співпраці. Було виділено чотири основні перешкоди стосовно групових форм роботи: відсутність навичок колаборачії, нерівномірна участь у роботі над спільним завданням, вищий статус компетентності деяких учасників та дружба. Наголошено на необхідності підготовки студентів до подолання ции перешкод. Викладені стратегї для їх уникнення, такі як розподіл ролей між членами групи, наявність постійних груп, невелика кількість людей у групі, навчання співпрацювати. Акцентовано на позитивних аспектах встановлення иілей сумісного навчання, приділення більшої уваги набуттю навичок сумісної роботи, необхіднх для ефективної співпрачі, та на наявності детальних критерїв для оцінювання того, як студенти праиюють у групах.
\end{abstract}

Ключові слова: сумісне навчання, групові форми роботи, навички сумісної роботи, викладання англійської мови, позитивна взаємозалежність, індивідуальна відповідальність, групова робота, команда робота.

Problem statement. Collaboration is one of the core 21-century skills that help students work as a team to achieve a common goal. Collaborative activities in the English classroom are especially essential with first-year students who are often not very-well prepared for group-work and effective collaboration. Moreover, their vision of teaching and learning, which is formed during school years neglects the importance of cooperative learning and is grounded on teacher-centred methodology. First-year students are often convinced that they can only learn from the teacher, not from each other; as a result, they are reluctant to accept group members as their collaborators. Students are often not prepared for "a great change from teacher dependence to learner interdependence, from teacher tutoring to peer tutoring, and from learning by collecting to learning by sharing" (Baloche, 1998, as cited in Tuan, 2010).

Furthermore, not all students equally participate in group work with "stronger" and diligent students taking on the initiative and responsibility while "weaker" or lazier students have passive roles. Moreover, students often revert to mother tongue when they are not observed, or even worse, start discussing unrelated topics.

Aim. This article explores how to prepare students for collaborative activities and build the culture of collaboration in the EFL (English as a Foreign Language) classroom. In addition, it suggests the repertoire of effective collaborative activities and strategies to mitigate the possible downsides of group activities.

Previous research. Cooperative learning (CL) is one of the most extensively research topics in education. A great number of studies have been conducted to investigate this approach in different levels of education, from a wide range of subject areas and across varied national contexts. These studies are unanimous is acknowledging its numerous benefits for student learning (Johnson \& Johnson, 1994; Slavin, 1995; Kagan, 1999). The data in these studies show that students who employ cooperative learning attain higher achievement level than those who learn under competitive and individualistic learning framework. In addition, cooperative learning activities are associated with higher-level thinking, depth of understanding of course material, self-esteem, good relations 
among students, etc. (Johnson \& Johnson, 1994; Slavin, 1995; Kagan, 1999).

The main material. While a variety of definitions of the term "cooperative learning" have been suggested, we will use the definition first introduced by the leaders of cooperative learning Johnson, Johnson, and Holubec who saw it as "the instructional use of small groups so that students work together to maximize their own and each other learning" (as cited in McCafferty et al., 2006: 5). In this paper, we will use the terms "cooperative learning" and "collaborative learning" interchangeably, although for some educators cooperative learning is a broader concept which includes specific principles as well as a number of recommendations for pair work and group work whereas collaborative learning refers simply to the use of pair-work and group work (McCafferty et al. 1, 2006; Anderson, 2019).

A large and growing body of literature has emphasized the importance of the two core principles of cooperative learning that need to be taken into account so that student-student interaction is successful. The first crucial concept is positive interdependence. It means working as a team towards a shared goal, not in competition with each other. This is the feeling among group members that they sink or swim together. Group's success depends on every member's contribution in the group. Positive interdependence encourages cooperation and the feeling of support (McCafferty et al., 2006). Without it, learners occasionally fall into the trap of "hitchhiking" where they let one learner do all the work for them, or of being "off task" (Cohen, 1994).

The second core concept of cooperative learning revealed in the literature is individual accountability. It exists when each individual member participates and meaningfully demonstrates their knowledge and skills. In other words, group success depends on contributions from all group members, making each learner accountable, both for their own learning and for contributing to the group as required (Anderson, 2019). With such an attitude, no one should hitchhike or free-ride on the efforts of others (Kagan, 1989).

Having looked into the discussion of the main features of CL, we will now move on to their implications for teaching. There are a large number of published studies that describe the challenges that occur among teachers who implement CL in classrooms. It has been noted that the underlying reason for such difficulties is that teachers often have a vague understanding of how to establish effective cooperative groups and manage their work (Cohen, 1994; Gillies et al., 2008).
Le, Janssen, and Wubbles (2018) presented an overview of the studies to date that explore the obstacles affecting the effectiveness of collaborative learning in daily classroom practice. The authors reported an impressive list of recent research related to unequal individual participation in group tasks, students' lack of communicative and collaborative skills, designing appropriate tasks, composing groups, managing class time, enhancing and monitoring productive collaboration.

One of the most common problems discussed in CL literature among students was lack of collaborative skills. In the higher education context, Popov et al. (2012) found that communication problems, caused by a lack of collaborative skills, may hinder first-year students from engaging in group work and contributing to group outcomes.

Teachers have reported facing challenges while structuring collaborative activities such as monitoring students' on-task behaviour, managing groupwork time, providing relevant materials, assigning individual roles, and establishing teamwork beliefs and behaviours (Gillies \& Boyle, 2010).

Another big concern on the part of teachers was assessment. Strom and Strom (2011) (as cited in Le et al., 2018) pointed out that the lack of assessment tools to measure students' collaborative efforts may lead to student disappointment about the transparency and evenness of the assessment.

To further investigate the obstacles to effective cooperation, Le et al. (2018) undertook a massive research project to study both teacher and student perceived features of collaborative activities that teachers have implemented to foster student collaboration. This comprehensive research approach resulted in some interesting findings.

Le et al. (2018) noted four main obstacles reported by students in relation to CL: lack of collaborative skills, free-riding, competence status, and friendship.

Lack of collaborative skills. The research revealed that all students agreed that they were not prepared to participate in group work effectively. Similarly, most of the teachers acknowledged that their students did not know how to collaborate effectively (Le et al., 2018).

Free-riding. The majority of the students pointed out unequal participation when working on group assignments. Some peers were very passive and reluctant to contribute to group tasks. This had a negative impact on the learning behaviours of all group members. On the other hand, low- and non-contributing students found it hard to participate in tasks and catch up with others. In agreement with the students, two-thirds of the teachers recognized the free-riding 
problem as well as their inability to grade low-contributing members (Le et al., 2018).

Competence status. Some students reported that high-status students dominated in the group because their ideas were generally accepted by the majority of group members without dispute. Consistent with students, teachers also witnessed that students were not able to participate equally and to use their full potential in group tasks, though the students who thought their status was high did not always perform better than those who thought of themselves as having lowstatus (Le et al., 2018).

Friendship. Students' feeling of friendship sometimes inhibited them to take the group discussion seriously and develop good arguments. Teachers also noted that students' friendship can be an obstacle in a way that they are easily off track the assigned topic (Le et al., 2018).

To further examine these obstacles to CL Le et al. (2018) analyzed their possible antecedents such as setting collaborative goals, instruction and assessment. They concluded that most teachers and students placed the main emphasis on the cognitive aspects of CL (i.e. they focused their attention predominantly on academic learning goals) and paid low attention to collaborative aspects. This imbalance in their attention was reflected in teachers' instructions with did not involve any advice on how to work collaboratively and a lack of explanation of how collaboration was going to be assessed.

Taken together, these studies show the importance of positive interdependence and individual accountability in CL; highlight the need for to train students to collaborate effectively taking into account such possible obstacles as free-riding, competence status, and friendship; indicated the positive aspects of setting CL goals, instructing students explicitly in the collaborative skills necessary for effective collaboration and having detailed criteria to assess how students work in groups.

Based on the insights from the literature, we have outlined some key collaborative activities that align with the core principles of CL. Further to this, we have described the strategies for facilitating and enhancing productive cooperation.

Collaborative activities for promoting positive interdependence and individual accountability.

The most commonly used cooperative learning activities which are instrumental in strengthening positive interdependence and individual accountability are as follows:

Jigsaw (Aronson et al., 1978). In Jigsaw, each group member obtains unique information, after that, they leave their original group and form an "expert group", typically same ability groups so that the learners most proficient in English get the most challenging text and those whose English is less proficient get an easier text (Anderson, 2019a). In "expert group" all students with the same piece of information get together, study it, and decide how best to teach it to their peers in the original groups. Next, students return to their original groups for the communication stage, when they share what they learned. Accordingly, students are prompt to help each other by telling their piece of material to the rest of the group. At the same time, they are expected to learn their information well and to do a good job of teaching their groupmates because the group is depending on them.

Circle the Sage. First, the teacher probes the class to see which students have something interesting to share. For instance, the teacher may ask who in the class has visited Paris. Those learners (the sages) go to different parts of the room. Then the rest of the group surrounds a sage, however no two members of the same team are allowed to join the same sage. The sage answers the question while the classmates listen, ask questions, and take notes. After that, all students return to their group. Each, in turn, explains what they learned. Because each one has gone to a different sage, they have different information. If there is disagreement, they stand up as a team. They resolve the disagreement by asking additional questions (as cited in Tuan, 2010).

Think-pair-share (TPS) (Lyman, 1978). Students listen to a question or presentation, have time to think individually, talk to each other in pairs, and finally share responses with the larger group. TPS gives students time to process information in the form of wait-time. Wait-time improves students' cognitive power. Students think of the ideas, share with their partner and then with the whole class. This step-bystep process makes students ready for discussions in larger groups.

Numbered Heads Together (Kagan, 1989). The procedure is as follows: Step 1: Students number off within teams. Step 2: The teacher asks a high consensus question. Step 3: Students put their heads together to make sure everyone on the team knows the answer. Step 4: The teacher calls a number at random, and students with that number raise their hands to be called upon to answer the question and earn points for their teams (as cited in Tuan, 2010).

Student Team Achievement Divisions (STAD). In STAD, the group is made up of four to five mixed ability members. Firstly, the teacher lectures to brief students on a topic. Then all students work together in a team. After that, students take quizzes individually 
on the subject. Here, they do not help one another. Individual members are given scores, and their scores are summed up to make the group score (as cited in Panhwar, 2016).

Strategies for enhancing and facilitating productive cooperation.

1. Assigning roles to group members. Cooperative learning suggests assigning roles in groups to enhance students' sense of individual accountability and to ensure their equal participation (Slavin, 1983, as cited in Panhwar, 2016). These roles include, e.g. leader, inquirer, timekeeper, recorder, presenter and spokesperson, and are supposed to be rotating so that every group member has the chance to perform each role.

2. Permanent groups. According to Anderson (2019b), most writers on cooperative learning generally recommend that we establish "home groups" of (ideally) four learners, which are mixed in ability, sex and other characteristics, choosing the learners for each of these heterogeneous groups carefully. Anderson (2019b) argued that it is worthwhile to put learners with the same level into "expert groups" both to provide variety and to prevent higher achievers from feeling like classroom assistants. As Anderson (2019b) noted, educators generally recommend keeping home groups together for one term and then changing composition to provide variety. Thus, learners get used to these groups, evolve into their individual roles within the group, which helps reduce con- flict and increase the value of peer-support and tuition Anderson, 2019b).

3. Keeping groups small. The generally agreed optimum group size for CL activities is four (Anderson, 2019b). If there is still a person who dominates the discussion, Anderson (2019b) suggests first to do the activity in pairs, and then to check their answer as a whole group, which increases the likelihood of all the learners participating.

4. Teach HOW to collaborate. This includes emphasizing the importance of collaboration in every lesson, providing a collaboration rubric, including collaboration in formative assessment. The main idea is to prepare students for collaborative activities and raise their awareness of acquiring cooperative skills.

Limitations. The collaborative activities and strategies that can be used effectively in CL are not limited to the ones described above. Also, assessment of CL is left beyond the scope of this article since this is a very broad topic which requires separate examination.

Conclusion. The main goal of this research was to explore the concept of cooperative learning to better understand how it can be used more effectively in teaching. First, we analyzed and synthesized the literature on the topic, which helped us identify important features of CL as well as some obstacles in teaching and learning. These insights laid the foundation for outlining the most instrumental collaborative activities in the English classroom as well as some strategies for their effective implementation.

\section{BIBLIOGRAPHY}

1. Anderson J. Deconstructing jigsaw activities. Modern English Teacher, 2019a. No. 28(2), pp. 35-37.

2. Anderson J. Cooperative learning: Principles and practice. English Teaching Professional. 2019b. No. 121, pp. 4-6.

3. Aronson E., Blaney N., Stephan C., Sikes J., \& Snapp M. The jigsaw classroom. Beverley Hills : Sage. 1978.

4. Cohen E. G. Restructuring the classroom: Conditions for productive small groups. Review of Educational Research, 1994. No. 64(1), pp. 1-35.

5. Gillies R., \& Boyle M. Teachers' reflections on cooperative learning: Issues of implementation. Teaching and Teacher Education, 2010. No. 26, pp. 933-940.

6. Gillies R. M., Ashman A. F., \& Jan Terwel J. (Eds). The teacher's role in implementing cooperative learning in the classroom: an introduction. Springer : Springer-Verlag US. 2008.

7. Johnson D. W., \& Johnson R. T. Learning together and alone (4th ed.). Boston : Allyn and Bacon. 1994.

8. Kagan S. The structural approach to cooperative learning. Educational Leadership, 1989. No. 47 (4), pp. 12-15.

9. Kagan S. Dimensions of cooperative classroom structures. In Slavin, R.E. et al (Eds.). Learning to cooperate, cooperating to learning. New York : Plenum press. 1999.

10. Le H., Janssen J., \& Wubbels T. Collaborative learning practices: teacher and student perceived obstacles to effective student collaboration. Cambridge Journal of Education, 2018. No. 48(1), pp. 103-122.

11. McCafferty S. G., Jacobs G. M., \& Iddings A. C. D. Cooperative learning and second language teaching. Cambridge: Cambridge University Press. 2006.

12. Panhwar A. H. Using cooperative learning to enhance student engagement with language support classes in Pakistani higher education (Unpublished doctoral dissertation). Anglia Ruskin University, Cambridge, UK. 2016.

13. Popov V., Brinkman D., Biemans H. J. A., Mulder M., Kuznetsov A., \& Noroozi O. Multicultural student group work in higher education. International Journal of Intercultural Relations, 2012. No. 36, pp. 302-317.

14. Slavin R. E. Cooperative learning: theory, research, and practice (2nd edition). Boston : Allyn and Bacon. 1995.

15. Smith R., \& Rebolledo P. A handbook for exploratory action research. London : British Council. Open Access. 2018.

16. Tuan L. T. Infusing cooperative learning into an EFL classroom. English Language Teaching, 2010. No. 3(2), pp. 64-77. 


\section{REFERENCES}

1. Anderson J. (2019a). Deconstructing jigsaw activities. Modern English Teacher, 28(2), 35-37.

2. Anderson J. (2019b). Cooperative learning: Principles and practice. English Teaching Professional 121, 4-6.

3. Aronson E., Blaney N., Stephan C., Sikes J., \& Snapp M. (1978). The jigsaw classroom. Beverley Hills: Sage.

4. Cohen E.G. (1994). Restructuring the classroom: Conditions for productive small groups. Review of Educational Research, 64(1), 1-35.

5. Gillies R., \& Boyle M. (2010). Teachers' reflections on cooperative learning: Issues of implementation. Teaching and Teacher Education, 26, 933-940.

6. Gillies R.M., Ashman A.F., \& Jan Terwel J. (Eds). (2008). The teacher's role in implementing cooperative learning in the classroom: an introduction. Springer: Springer-Verlag US.

7. Johnson D. W., \& Johnson R. T. (1994). Learning together and alone (4th ed.). Boston: Allyn and Bacon.

8. Kagan S. (1989). The structural approach to cooperative learning. Educational Leadership, 47 (4), $12-15$.

9. Kagan S. (1999). Dimensions of cooperative classroom structures. In Slavin, R.E. et al (Eds.). Learning to cooperate, cooperating to learning. New York: Plenum press.

10. Le H., Janssen J., \& Wubbels T. (2018) Collaborative learning practices: teacher and student perceived obstacles to effective student collaboration. Cambridge Journal of Education, 48(1), 103-122.

11. McCafferty S. G., Jacobs G. M., \& Iddings A. C. D. (2006). Cooperative learning and second language teaching. Cambridge: Cambridge University Press.

12. Panhwar A. H. (2016). Using cooperative learning to enhance student engagement with language support classes in Pakistani higher education (Unpublished doctoral dissertation). Anglia Ruskin University, Cambridge, UK.

13. Popov V., Brinkman D., Biemans H. J. A., Mulder M., Kuznetsov A., \& Noroozi O. (2012). Multicultural student group work in higher education. International Journal of Intercultural Relations, 36, 302-317.

14. Slavin R. E. (1995). Cooperative learning: theory, research, and practice (2nd edition). Boston: Allyn and Bacon.

15. Smith R., \& Rebolledo P. (2018). A handbook for exploratory action research. London: British Council. Open Access.

16. Tuan L. T. (2010). Infusing cooperative learning into an EFL classroom. English Language Teaching, 3(2), 64-77. 